\title{
Image Filters: Effects of Emotion Displays on Followers' Perceptions of Principled Leaders
}

Flávia Cavazotte ${ }^{1}$ Daniel Martins Abelha ${ }^{1}$ Lucas Martins Turano ${ }^{1}$

${ }^{1}$ Pontifícia Universidade Católica do Rio de Janeiro, Rio de Janeiro, RJ, Brazil

Received 09 December 2019. This paper was with the authors for two revisions. Accepted 04 April 2021.

First published online 19 April 2021.

Editor-in-chief: Carlo Gabriel Porto Bellini (D) (Universidade Federal da Paraíba, João Pessoa, PB, Brazil)

Associate editor: Patrícia Martins Fagundes Cabral (ID) (Universidade do Vale do Rio dos Sinos, São Leopoldo, RS, Brazil)

Reviewers: Nuno Rebelo dos Santos (10) (Universidade de Évora, Évora, Portugal), Clarissa Socal Cervo (Universidade Federal Fluminense, Niterói, RJ, Brazil) and one anonymous reviewer

Editorial assistants: Kler Godoy and Simone Rafael (ANPAD, Maringá, PR, Brazil) 


\begin{abstract}
We analyze how followers respond to principled and unprincipled leaders as they express positive and negative emotions, based on the moral tenets of authentic leadership theory. Grounded on the theoretical principles of emotion contagion and cognitive interpretation, we propose that negative affective displays taint followers' perceptions of authentic leaders and that positive affective displays brighten followers' perceptions of inauthentic leaders. We tested these hypotheses in two laboratory experiments. Results indicate that while negative affective displays significantly disfavored perceptions about an authentic leader, positive affective displays did not favor attitudes about the leader. In contrast, positive affective displays not only favored attitudes toward an inauthentic leader but also positively influenced judgments regarding the leader's ethicality. Passive negative displays led to more favorable attitudes toward an inauthentic leader than active negative displays. Our findings unveil followers' susceptibility to distant leader's emotion displays, highlighting the nexus among leadership, emotions, and ethics, as well as their relevance in the organizational and political arenas.
\end{abstract}

Keywords: principled leadership; authentic leadership; inauthentic leadership; leader distance; emotion displays

JEL Code: D910 


\section{INTRODUCTION}

The toxic outcomes provoked by unprincipled leaders and their damaging impacts on organizations and society have expanded the debate about virtue and vice for those in positions of power (Avolio \& Gardner, 2005; Fehr, Yam, \& Dang, 2015). Nevertheless, we still know little about the intersections between leader affective displays and principled leadership, particularly the influence of emotion expression for leaders who endorse high moral standards or oppose them. Given the role of emotions in social interaction and influence (Van Knippenberg \& Van Kleef, 2017), positive and negative emotion displays might interfere with how we process information regarding these leaders, even when they clearly approve moral or immoral standards in discourse. Despite its relevance, knowledge on how affective displays by principled and unprincipled leaders influence followers is scant, as the topic has been largely overlooked by scholars in the field.

In this study, we examine how positive and negative affective displays influence perceptions about principled and unprincipled leaders in the context of leader-follower distance. Leadership at a distance has long been of concern to scholars focused on the political arena (Burns, 1978; Gardner, 1990), while research among organizational leadership scholars has been rarer (Antonakis \& Atwater, 2002). Nevertheless, although distant leaders have little interactions with followers, they still can have a strong impact on their attitudes and behaviors (Kunst, Dovidio, \& Thomsen, 2019). Based on theories of emotion contagion (Barsade, 2002; Hatfield, Cacioppo, \& Rapson, 1992) and emotion cognitive interpretation (Lewis, 2000; Tiedens \& Linton, 2001), we argue that despite the strong moral convictions of principled leaders, when they are distant from followers their displays of negative affect will cast a shadow on them and on how they will be perceived, and therefore negatively affect followers' judgments about the leader, leading to less favorable outcomes. Conversely, displays of positive affect will brighten up perceptions about unprincipled leaders that are distant from followers, and therefore lead to more favorable follower judgments, including assessments of leader ethicality.

While researchers have investigated whether and how the expression of positive and negative affect influences follower perceptions of transformational and charismatic leadership (Bono \& Ilies, 2006; Chi, Chung, \& Tsai, 2011; Johnson, 2009), such leadership perspectives do not particularly address principled leadership (Bass, 1999). On the other hand, authentic leadership theory emerged based on the assumption that morality, balance, and positivity are central attributes of effective leaders (Avolio, Wernsing, \& Gardner, 2017; Gardner, Cogliser, Davis, \& Dickens, 2011; Luthans \& Avolio, 2003). In this study, we focus on the moral principles that ground authentic leadership theory and examine if the expression of positive and negative emotions by authentic and inauthentic leaders influences three follower reactions: perception of leader efficacy, identification with the leader, and assessments of leader ethicality. Our findings contribute to broadening knowledge about the interplay between affective displays and principled leadership, based on a robust research design. Our observations also have important practical implications for leadership development and public relations. 


\section{THEORETICAL BACKGROUND AND HYPOTHESIS}

\section{Emotions and leadership}

In the last decades, the study of affect in organizational settings has increasingly attracted the attention of scholars. While moods are diffuse and lasting affective states not explicitly attached to a particular object or cause, emotions are discrete feelings with a clear object or cause that last for short periods (Brief \& Weiss, 2002; Weiss \& Cropanzano, 1996). Positive emotions (e.g., happiness; enthusiasm; pride) and negative emotions (e.g., sadness; fear; anger) are unambiguous, whereas mood states are less specific, and tend to be treated more generally in empirical studies under the scope of positive and negative states (Watson \& Clark, 1997). Besides valance, emotions are also differentiated by their level of physiological arousal: anger is considered an active negative emotion and sadness is considered a passive negative emotion.

In social interactions such as leadership processes, both leaders and followers are always feeling and expressing various emotions. While leaders can and at times will express how they feel verbally, they constantly display emotions through non-verbal communication, such as movements, facial expressions, and tone of voice. Such displays cue their affective states to followers and will also affect their affective reactions, behaviors, and judgments about the leaders (Chi et al., 2011; Erez, Misangyi, Johnson, LePine, \& Halverson, 2008; Newcombe \& Ashkanasy, 2002).

Research on leadership and emotion has addressed how leader affect influences follower affect, attitudes, and behaviors, such as citizenship and voluntary turnover (Gooty, Connelly, Griffith, \& Gupta, 2010; Van Knippenberg \& Van Kleef, 2017). Leaders can influence the emotions and moods of their teams (Sy, Côté, \& Saavedra, 2005), which in turn can affect organizational outcomes, such as customer satisfaction (George, 1996). In addition, the expression of emotions by leaders seems to influence the way they are perceived and evaluated (Bono \& Ilies, 2006; Madera \& Smith, 2009; Johnson, 2009).

In particular, the impact of leader's emotion displays on followers and their assessments about the leader has been the focus of multiple studies (Bono \& Ilies, 2006; Gaddis, Connelly, \& Mumford, 2004; Lewis, 2000; Montepare \& Dobish, 2003; Newcombe \& Ashkanasy, 2002). Some researchers have observed that the expression of positive emotions by a leader is positively related to follower evaluations about the leader and their perceived attractiveness (Bono \& Ilies, 2006; Newcombe \& Ashkanasy, 2002). Studies have also suggested that the expression of negative emotions by leaders tends to hurt evaluations about them (Gaddis et al., 2004; Lewis, 2000).

'Cognitive interpretation' and 'emotion contagion' are psychosocial mechanisms that help explaining followers' reactions to leaders' affective displays. Research on the former indicates that affective displays convey information that can be used by observers to make attributions about a target (Lewis, 2000; Tiedens \& Linton, 2001; Van Kleef, 2009). Followers tend to appraise leaders according to certain social norms - sadness, for instance, might be interpreted as lack of selfconfidence (Kirkpatrick \& Locke, 1991; Sutton \& Rafaeli, 2017), while anger might be associated with attributions of higher status by observers (Tiedens \& Linton, 2001).

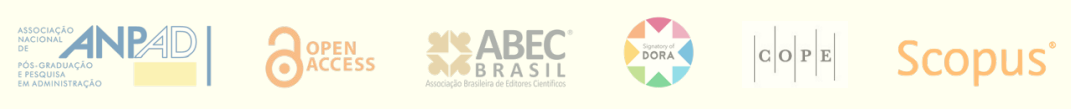


In addition, when someone displays an emotion, such affective state tends to awaken the same emotion on observers, a process known as 'emotional contagion' (Barsade, 2002; Hatfield et al., 1992). Such process can profoundly affect observers and influence their perceptions and judgments in ways that follow the valence of the affect expressed. Based on this principle, research suggests that affective states displayed by a leader would influence affective states of followers, and therefore tint their attitudes, including their assessments about the leader. In support to this idea, George (1996) stated that "when leaders feel excited, enthusiastic, and active, they may be more likely to energize their subordinates and convey a sense of efficacy, competence, optimism, and enjoyment" (George, 1996, p. 162).

Various authors have carefully examined the question of emotional contagion (Grossman, 2000; Ilies, Fulmer, Spitzmuller, \& Johnson, 2009; Sy et al., 2005; Van Kleef, 2009). Sy, Côté, and Saavedra (2005) observed that members of a group show more positive mood when leaders also display that affective state, suggesting the contagion of emotions between agents. Furthermore, the studies of Ilies, Fulmer, Spitzmuller, and Johnson (2009) highlighted that the positive affectivity of leaders creates a more positive working environment, thus promoting better productivity. In addition, the expression of emotions viewed as appropriate by followers should enhance the legitimacy of leaders, who are perceived as more effective through emotional contagion (Rajah, Song, \& Arvey, 2011).

Although several studies investigated positive emotion displays of leaders, only a few have examined effects of negative affective displays (Gooty et al., 2010; Johnson, 2009; Van Kleef, 2009). Overall, these studies tend to conclude that negative affective displays disfavors leaders when compared to positive displays, although some studies suggest that this influence may vary as a function of the affective state of followers and other characteristics (Damen, Van Knippenberg, \& Van Knippenberg, 2008).

Visser, Van Knippenberg, Van Kleef, and Wisse (2013) observed that when distant leaders express emotions of happiness and sadness at work, their subordinates tend to favor those who display happiness in performance ratings, rather than those who show sadness. In another study, it was observed that positive emotions, such as happiness expressed through smiling and attentive visual contact, were associated with a more favorable assessment of leader effectiveness, in contrast with negative emotions, such as sadness and expressions of resignation through a downcast visual posture and grim visage (Bono \& Ilies, 2006).

Although such studies have observed the role of affective displays on assessments of leaders, they largely focused on such effects on perceptions about transformational and charismatic leaders (Bono \& Ilies, 2006; Chi et al., 2011; Johnson, 2009). To that effect, findings have primarily confirmed that displays of positive affect benefit leaders and assessments about them. Nevertheless, studies on the interplay between principled leadership and affective displays are surprisingly scarce. 


\section{Principled leadership: the lens of authentic leadership theory}

Since the beginning of the twenty-first century, problems such as climates change, economic strains, and political tensions have spurred the debate about positive forms of leadership, increasing the concern with value-based leadership in the academic literature (Dinh et al., 2014). Among the frameworks that share such emphasis, authentic leadership theory has attracted considerable interest from business and leadership researchers (Dinh et al., 2014; Gardner, Cogliser, Davis, \& Dickens, 2011). The theory was conceived as a 'root concept' - the fundamental basis and mandatory essence of any kind of positive leadership (Avolio \& Gardner, 2005).

Although the literature on authentic leadership has suffered from mixed levels of rigor (Avolio et al., 2017; Gardner et al., 2011), seminal conceptualizations brought attention to the role of principled, sensible, and selfless forms of leadership to tackle the many challenges that organizations and society face today. These conceptions have focused on positive psychological capacities and leader behaviors that stimulate these same capacities among employees, therefore fostering positive ethical climates in organizations (Avolio, Gardner, Walumbwa, Luthans, \& May, 2004; Ilies et al., 2009; Luthans \& Avolio, 2003). Foundational frameworks on the topic also emphasize the role of authentic leadership development (Avolio \& Gardner, 2005; Luthans $\&$ Avolio, 2003), proposing that it should focus on leaders' self-concepts and their connections with leader behaviors, highlighting the role of self-awareness and positive self-regulation in authentic leadership development.

Through the years, many authors have offered different notions for what authentic leadership entails (Gardner et al., 2011). Ilies et al. (2009) define authentic leaders as those who are "deeply aware of their values and beliefs, they are self-confident, genuine, reliable and trustworthy, and they focus on building followers' strengths, broadening their thinking and creating a positive and engaging organizational context" (Ilies et al., 2009, p. 374). George (2003) describe authentic leaders as

genuine people who are true to themselves and to what they believe in. They engender trust and develop genuine connections with others ... as they develop as authentic leaders, they are more concerned about serving others than they are about their own success or recognition (George, 2003, p. xxxi).

Therefore, a core tenet of this perspective is that leadership roles "carry a responsibility to act morally and in the best interests of others" (Avolio et al., 2004, p. 807).

Authentic leadership has been operationalized based on four core components (Neider \& Schriesheim, 2011; Walumbwa, Avolio, Gardner, Wernsing, \& Peterson, 2008): (1) 'self-awareness,' (2) 'relational transparency,' (3) 'balanced information processing,' and (4) 'internalized moral perspective.' These four dimensions have grounded subsequent empirical studies on authentic leadership (Avolio et al., 2017; Gardner et al., 2011; Neider \& Schriesheim, 2011). Authentic leaders demonstrate high 'self-awareness,' i.e., the capacity to acknowledge their own talents and limitations, and to consider, evaluate, and reformulate their own position and behavior based on feedback from followers (Avolio et al., 2004; George, 2003). Authentic leaders also show 'balanced information

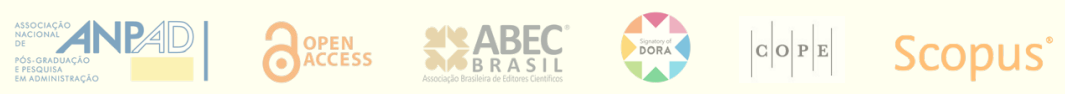


processing,' i.e., impartiality when weighing relevant information available to them when deciding. Leaders who have this attribute seek and consider the advice of other individuals before they act. In addition, initial perspectives describe the authentic leader as an individual of character that behaves with high levels of integrity (May, Chan, Hodges, \& Avolio, 2003). These leaders act based on moral values, they are true to principles of what is right and wrong (Gardner, Avolio, Luthans, May, \& Walumbwa, 2005). Through an 'internalized moral perspective,' the leader does not yield to external or hierarchical pressures. Finally, 'relational transparency' involves honestly expressing feelings, thoughts and even relevant information when dealing with others.

While research has explored the impact of authentic leaders on the psychological state and affective reactions of followers (Peus, Wesche, Streicher, Braun, \& Frey, 2012; Wang, Sui, Luthans, Wang, \& Wu, 2014), the literature on emotion expression and authentic leadership is scant. Since emotions and emotional expression are important elements in interpersonal exchanges and leadership processes (Gooty et al., 2010; Sy et al., 2005; Van Knippenberg \& Van Kleef, 2017), and given that authentic leadership is grounded on principles of positive emotional influence between these leaders and their followers, research on how affective displays affect the effectiveness of authentic leaders is also relevant to advance theory in the field.

\section{Emotion displays and reactions to authentic leaders}

As mentioned before, studies have observed associations between emotions and leadership mainly in the literature on transformational/transactional and charismatic perspectives. However, few studies have investigated the influence of leader affective displays in the context of principled leadership. In addition, studies on the effectiveness of principled forms of leadership have seldom addressed the role of positive and negative emotion expression for value-based leadership. While scholars have discussed emotional information and social information processing with respect to the experience and expression of 'moral' emotions by leader and followers, such as shame, embarrassment, and guilt (Haidt, 2003) - which are quite consequential in leadership processes and are certainly often felt by leaders and followers -, these emotions are probably less openly expressed when compared to happiness, sadness, and anger.

The framework proposed by Avolio, Gardner, Walumbwa, Luthans, and May (2004), which elaborates on the relationship between authentic leadership and followers' attitudes, behaviors, and performance, stresses the potential effects that positive emotions and trust would have in authentic leadership processes. According to Lord and Brown (2004), in general, earlier leadership theories focused more on cognitive elements than on affective and emotional processes. The work of Avolio, Gardner, Walumbwa, Luthans, and May (2004) filled this gap, by analyzing the relationship between authentic leadership and positive psychological capacities on both leaders and followers. Emotions are therefore central to the theory of authentic leadership. Besides, by instilling positive moods and emotions in followers, authentic leaders should be able to increase the confidence and promote the well-being and engagement of all followers within an organization (Avolio et al., 2004).

Michie and Gooty (2005) also suggested the importance of affect for authentic leadership, discussing the need to study specific emotions that would distinguish authentic from inauthentic

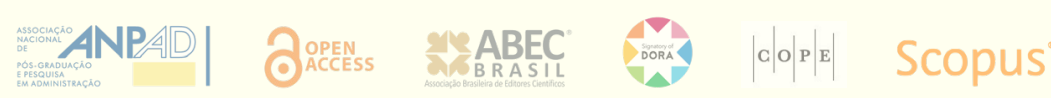


leaders (e.g., temperance, gratitude, love, etc.). These authors contend that when leaders experience such emotions, they act with more self-transcendent values, modeling selftranscendent behaviors in their group. Thus, when a leader displays these emotions, perceptions of authenticity would be stronger as well as the identification with the leader.

Positive affectivity in leaders is an important element in authentic leadership theory, which suggests that such leaders will always arouse positive affective reactions on their followers (Avolio et al., 2004; Gardner et al., 2005). Nevertheless, based on the tenets of cognitive interpretation and emotion contagion, the display of positive and negative emotions by authentic leaders can favor or taint follower judgments about the leader. This would be so because affective displays can engender states of similar valence in observers (contagion) and entail information that observers take into account when making judgments (cognitive interpretation). Thus, we propose that the expression of positive emotions will tend to yield more favorable appraisals of authentic leaders by followers, highlighting perceptions of effectiveness and follower identification with the leader, while negative affective displays will function as a filter, shadowing the virtues of authentic leaders in a manner similar to what was observed in the literature about other leadership perspectives (Bono \& Ilies, 2006; Chi et al., 2011; Johnson, 2009; Madera \& Smith, 2009).

H1: Authentic leaders who display positive affect will be perceived as more effective.

H2: Authentic leaders who display negative affect will be perceived as less effective.

H3: Followers will identify more strongly with authentic leaders who display positive affect.

H4: Followers will identify less strongly with authentic leaders who display negative affect.

\section{Emotion displays and reactions to inauthentic leaders}

The literature on authentic leadership has generally focused on virtues such as morality, transparency, self-knowledge, and selflessness. In social interactions, a leaders' degree of commitment to their true selves is said to determine their relative authenticity, i.e., if they honestly express what they genuinely think and believe (Luthans \& Avolio, 2003). Therefore, as highlighted by Avolio and Gardner (2005) in their seminal work, leaders are not entirely and constantly authentic; authenticity is an attribute that varies in degree. Follower perceptions of leader authenticity are based on the display of exemplary behaviors by leaders and the unfolding judgments that they are trustworthy, responsible, and a person of integrity (Gardner \& Avolio, 1998). Authors have also called attention to relational authenticity - through their open and trusting relationships with followers, authentic leaders would stimulate leader-follower identification and attributions of leader integrity (Spitzmuller \& Ilies, 2010).

Inauthentic leadership, on the other hand, has attracted little academic attention. Nevertheless, examples of inauthentic leaders abound in society, both in public and private spheres (Gardner et al., 2005). Early perspectives have associated inauthenticity with excessive plasticity in playing social roles, as when leaders attempt to overly fit authority prototypes (Seeman, 1966).




Nevertheless, Henderson and Hoy (1983) defined inauthentic leaders as those who 'pass the buck,' blame others for errors and negative outcomes, are manipulative of subordinates, and tend to demonstrate a salience of role over self. Later conceptualizations have focused on authenticity in light of positive psychology, and describe inauthentic leaders as manipulative individuals whose rhetoric is a game plan to achieve personal gain, and who lack the positive influence that authentic leaders would promote on followers (Avolio \& Gardner, 2005).

Although thorough conceptualizations of inauthentic leadership are rare, it was early defined as the extent to which leaders conceal information, manipulate others, and show a predominance of role over self in their behaviors (Henderson \& Hoy, 1983). Scholars have asserted that inauthentic leaders manipulate followers for their own 'self-serving purposes,' which may also be unethical (Bass \& Steidlmeier, 1999; Dasborough \& Ashkanasy, 2005); that their motivations are self-centered and 'disregard the needs of others', including organizations and their stakeholders (Conger, 1990); that they 'fail to recognize moral dilemmas' and can be 'dishonest and deceptive' (Bass \& Steidlmeier, 1999; May et al., 2003). In addition, Avolio, Gardner, Walumbwa, Luthans, and May (2004, p. 806) proposed that what differentiates the authentic and the inauthentic leader goes beyond leadership style. They argue that transformational leaders, for instance, could still be directive or even authoritarian, implying that such leader behaviors are the antithesis of authentic leadership. Therefore, in this study we conceive inauthentic leadership as leader behaviors that convey a deceitful and self-centered relational stance: instead of a moral grounding, they lack moral principles; instead of being transparent, they are deceptive; instead of self-awareness, they show thoughtlessness; and instead of balance in information processing, they act with arrogance.

Morality is inherent to the construct of authentic leadership (Avolio \& Gardner, 2005) - in the literature, we can observe strong connections between authentic and moral leadership (Ladkin \& Taylor, 2010), as theories of ethics have influenced theory development in the field (Gardner et al., 2011). Hence, the absence of principles and sneakiness should be central aspects of inauthentic leadership. Inauthentic leaders favor dishonesty and might even build a false image that conceals their focus on personal interests in detriment to collective ones (Rubin, Dierdorff, Bommer, \& Baldwin, 2009). Unlike the openness of authentic leaders, inauthentic leaders are likely to be intrinsically competitive and egocentric, even if at times behind a false aura of affability - a characteristic also discussed in the literature on Machiavellian (Deluga, 2001), cynic (Neves, 2012), and narcissistic leadership (O'Reilly, Doerr, Caldwell, \& Chatman, 2014).

In contrast to self-awareness and the balanced decision process that mark authentic leaders, both signs of their intrinsic selflessness, inauthentic leaders will be inflated by self-centered arrogance and often neglect others: their impact on them as well as their inputs on issues. These leaders are often self-interested and seek power at the expense of others; but even if they disguise their callous intention under false displays of benevolence, it can backfire if followers pick up on their inauthentic displays (Den Hartog \& Belschak, 2012). Over time, such self-centered relational stance may even interfere with goal achievement (Xu, Loi, \& Lam, 2015). This facet of inauthentic leadership has also been addressed in studies on despotic (Naseer, Raja, Syed, Donia,




\& Darr, 2016), tyrannical (Kant, Skogstad, Torsheim, \& Einarsen, 2013), and abusive leadership (Harvey, Harris, Gillis, \& Martinko, 2014).

Authors in the field have proposed that the power of inauthentic leaders is short-lived, suggesting that their manipulative behaviors, dishonesty, and deception not rarely lead to losses in reputation (Gardner et al., 2005). Workers who interact with inauthentic leaders may feel emotionally drained, and as a defense mechanism, remain silent and avoid confrontation with these leaders in the workplace (Xu et al., 2015). When inauthenticity meets power, followers' ability to resist, oppose, or avoid the leader can become challenging. As a consequence, a climate of mistrust is created, hampering meshing in the organization (Schyns \& Schilling, 2013) and organizational effectiveness (Rubin et al., 2009; Koning \& Kleef, 2015). Therefore, leaderfollower identification and attributions of leader integrity should be, in general, less likely among followers of inauthentic leaders (Spitzmuller \& Ilies, 2010).

However, if inauthentic leaders display positive emotions, they are likely to provoke positive emotions on their followers through the process of emotional contagion, i.e., by arousing emotions of similar valence on their followers (Barsade, 2002; Hatfield et al., 1992). Leaders who display positive emotions tend to be more likable; they receive better appraisals of their performance and attract stronger personal identification (Bono \& Ilies, 2006; Johnson, 2008; Joseph, Dhanani, Shen, Mchugh, \& Mccord, 2015). In addition, how the observers label and interpret what they see is tainted by the arousal provoked by positive affective displays (Lewis, 2000; Tiedens \& Linton, 2001). A study conducted with participants from different cultures revealed that when a leader externalizes empathetic emotions (even if they are not felt), they tend to receive a more favorable appraisal of their performance (Sadri, Weber, \& Gentry, 2011). Thus, the expression of positive emotions can lead to more favorable judgments about these leaders. Therefore, we propose the following hypotheses:

H5: Inauthentic leaders who display positive affect will be perceived as more effective than (a) inauthentic leaders who display passive negative affect (sadness) and (b) inauthentic leaders who display active negative affect (anger).

H6: Followers will identify more strongly with inauthentic leaders who display positive affect than with (a) inauthentic leaders who display passive negative affect (sadness) and (b) inauthentic leaders who display active negative affect (anger).

Similarly, it seems that positive affective displays, which influence leadership through emotional contagion and social cognitive processing, might not only affect appraisals of competence, personal identification, and relational trust in regard to leaders, but also compromise judgments about their ethical conduct (Rajah et al., 2011). Followers of distant leaders will tend to react more strongly to emotional cues. Aware of the power those emotions can bring to persuasive communication, inauthentic leaders might even exploit emotions - studies have shown that the facial expressions of such leaders can impair their observer's perceptions (Olivola, Eubanks, \& Lovelace 2014; Trichas $\&$ Schyns, 2012). Studies have also shown that the likableness of an offender can attenuate harsh attitudes and forgiveness (Bradfield \& Aquino, 1999). Therefore, based on the tenets of cognitive

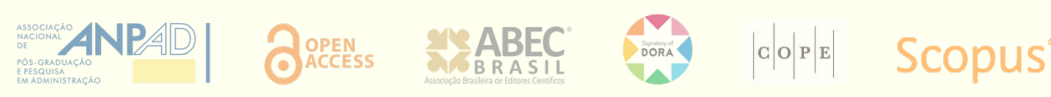


interpretation and emotion contagion, as well as the very few studies on the topic, we expect that the expression of positive emotions will not only favorably influence judgments about inauthentic leaders, but also affect attributions about their ethicality.

In addition, Madera and Smith (2009) observed that leaders who displayed sadness in the context of an organizational crisis were appraised more favorably regarding their performance than those who displayed anger. Other researchers have also observed that leaders who show anger are more perceived as tyrants, causing stronger hostility among subordinates, in sharp contrast to ethical and authentic leadership in general (Kant et al., 2013; Matthiesen \& Einarsen, 2007). We also believe that passive negative emotion displays will lead to more favorable assessments of a leader's ethicality than active negative displays. Therefore, we propose the following hypotheses:

H7: Inauthentic leaders who display positive affect will be considered more ethical than (a) inauthentic leaders who display passive negative affect (sadness) and (b) inauthentic leaders who display active negative affect (anger).

H8: Inauthentic leaders who display passive negative affect (sadness) will be considered more ethical than inauthentic leaders who display active negative affectivity (anger).

\section{EXPERIMENT - STUDY 1}

\section{Design}

We hired a professional actor who recorded videos playing the role of CEO for a fictitious company. In these videos, the CEO presents the company to new employees, endorsing authentic leadership principles and values in his speech. The address was developed based on items from the Authentic Leadership Questionnaire (ALQ - distributed by Mind Garden, Inc. www.mindgarden.com, retrieved on February 11, 2015). Items for the authentic leadership dimensions found in the instrument were adapted to form statements in the leader's discourse, scripted in a way close to conversational speech. The actor was a 55-year-old male and recorded the video in an actual executive suite.

We prepared three videos, one with the actor delivering the speech while displaying positive emotions - experimental condition (1), one while displaying negative emotions - experimental condition (2), and a control video with the actor delivering the same speech with a neutral emotional tone.

\section{Participants}

A sample comprised of 172 senior majors enrolled in regular undergraduate programs at a wellknown southeastern university participated in the study. Eighty-nine participants were males (51.74\%), and 83 were females (48.26\%). The average age was 21 years $(\mathrm{SD}=2.76)$, and $34.3 \%$ stated they were employed. Participants were randomly assigned to watch one of the three videos.
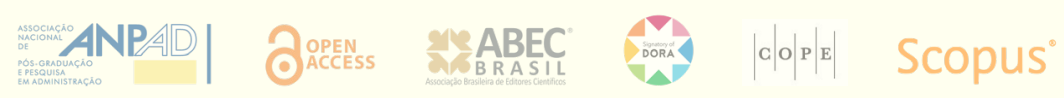
The total number of participants per group was 55 in experimental condition 1 (positive emotion display), 62 in experimental condition 2 (negative emotion display), and 55 in the control group.

Table 1

Demographic and descriptive statistics by conditions - study 1

\begin{tabular}{|c|c|c|c|c|c|c|c|c|}
\hline \multirow{2}{*}{$\begin{array}{c}\text { Variables } \\
\text { Gender }\end{array}$} & \multicolumn{2}{|c|}{ Positive Affect } & \multicolumn{2}{|c|}{ Control } & \multicolumn{2}{|c|}{ Negative Affect } & \multicolumn{2}{|c|}{ Total } \\
\hline & $41.8 \% \mathrm{~F}$ & $58.2 \% \mathrm{M}$ & $56.4 \% \mathrm{~F}$ & $43.6 \% \mathrm{M}$ & $46.8 \% \mathrm{~F}$ & $53.2 \% \mathrm{M}$ & $48.3 \% \mathrm{~F}$ & $51.7 \% \mathrm{M}$ \\
\hline Age & \multicolumn{2}{|c|}{$\bar{X}=20.84 \mathrm{SD}=2.30$} & \multicolumn{2}{|c|}{$\bar{X}=22.04 \mathrm{SD}=3.32$} & \multicolumn{2}{|c|}{$\bar{X}=20.56 \mathrm{SD}=2.42$} & \multicolumn{2}{|c|}{$\bar{X}=21.12 \mathrm{SD}=2.76$} \\
\hline Grade Point Average & \multicolumn{2}{|c|}{$\bar{X}=7.51 \mathrm{SD}=.88$} & \multicolumn{2}{|c|}{$\bar{X}=7.3 \mathrm{SD}=.70$} & \multicolumn{2}{|c|}{$\bar{X}=7.24 \mathrm{SD}=1.08$} & \multicolumn{2}{|c|}{$\bar{X}=7.33 \mathrm{SD}=.90$} \\
\hline Work Experience & $41.8 \% \mathrm{Y}$ & $58.2 \% \mathrm{~N}$ & $34.5 \% \mathrm{Y}$ & $65.5 \% \mathrm{~N}$ & $27.4 \% \mathrm{Y}$ & $72.6 \% \mathrm{~N}$ & $34.3 \% \mathrm{Y}$ & $65.7 \% \mathrm{~N}$ \\
\hline Participants & \multicolumn{2}{|c|}{55} & \multicolumn{2}{|c|}{55} & \multicolumn{2}{|c|}{62} & \multicolumn{2}{|c|}{172} \\
\hline
\end{tabular}

\section{Procedure}

All the sessions presenting the videos to the three groups took place in the same day and time. Before watching the video, participants were told they were going to watch a message the CEO of a company recorded for newly hired employees. As for ethical aspects, the participants received a free and informed consent form stating the objective of the research, its context, the voluntary nature of their participation, guarantees regarding the anonymity and confidentiality of the information provided, the right to withdraw from the research at any time, as well as the necessary guidelines for the correct filling of the questionnaire. After watching the video, participants filled in the questionnaire. They were instructed not to speak to each other after watching the videos.

\section{Measures}

'Affective states' - We applied the 15-item questionnaire developed by McNair, Lorr, and Droppelman (1971) to assess the participants' judgment of the leader's emotional state. Some examples of items are:

"The leader is happy" and "The leader is despondent".

Participants evaluated the leader by scoring the items on a seven-point scale, ranging from (1) totally incorrect to (7) totally correct. The Cronbach's alpha for this measure is 0.92.

'Perception of leader efficacy' - We formulated three items to assess attributions about the leader's effectiveness:

"This CEO is a good leader," "My productivity would increase with a leader like this," and "I think this leader would perform well in my area of work".

Participants ranked the leader's efficacy on a five-point Likert scale. Cronbach's alpha of this scale was 0.83 . 
'Identification with the leader' - We formulated three items to assess follower identification with the leader. These items were:

"This CEO fits my image of a leader," "I identify with this leader," and "I'd like to have this CEO as my formal leader".

As before, participants evaluated the degree of identification with the leader on a five-point Likert scale. Cronbach's alpha of the scale was 0.90 .

'Authentic leadership' - We applied the Authentic Leadership Questionnaire (ALQ) (distributed by Mind Garden, Inc. - www.mindgarden.com, retrieved on February 11, 2015) (Avolio et al., 2017; Walumbwa et al., 2008). This instrument aims to evaluate authentic leadership as perceived by followers. It comprises 16 items that reflect the four dimensions proposed by the theory. Some examples are:

"The leader makes decisions based on high standards of ethical conduct" and "The leader shows that he understands how his actions affect others."

Participants evaluated the leader by scoring the items on a five-point Likert scale. The Cronbach's alpha for this scale is 0.84 .

'Demographic data' - We asked the participants to answer additional questions on gender, age, grade point average, whether they were working, and how many years of work experience they had.

\section{Results}

Initially, we verified the effect of the experimental manipulation of the leader's emotion display (positive, negative). The ANOVA results indicated that there were significant differences between the means of the three groups $(F=99.55 ; \mathrm{p}<0.001)$. We performed a post-hoc test (Tukey HSD) to obtain multiple comparisons between the groups. The results indicated that the manipulation was successful and that there were significant differences in the perceptions of the leader's emotion displays between the three groups. In experimental group 1 (positive affect), participants' assessments of the authentic leader's affectivity was significantly higher $(\bar{X}=5.52$; $S D=0.88)$, followed by the control group $(\bar{X}=4.84 ; S D=0.93)$ and by experimental group 2 (negative affect), with a significantly lower mean $(\bar{X}=3.34 ; \mathrm{SD}=0.77)$.

Table 2 displays the descriptive statistics, Pearson correlations, and Cronbach's alphas for the variables in the study. The dependent constructs 'leader efficacy' and 'identification with the leader' had good internal consistency. As expected, there were no systematic differences between the experimental groups and the demographic variables and there were significant variations in the dependent variables between the conditions. Judgments about leader efficacy were more stringent for older individuals.




Table 2

Descriptive statistics, Pearson correlations, and Cronbach's alphas

\begin{tabular}{|c|c|c|c|c|c|c|c|c|c|}
\hline Variables & AVG & SD & $\mathrm{Ca}$ & 1 & 2 & 3 & 4 & 5 & 6 \\
\hline 1. Condition ${ }^{\mathrm{a}}$ & - & - & & & & & & & \\
\hline 2. Gender ${ }^{b}$ & - & - & & .04 & & & & & \\
\hline 3. Age & 21.12 & 2.76 & & .05 & .12 & & & & \\
\hline 4. Experience & 2.30 & 2.48 & & -.03 & -.02 & $.67^{* *}$ & & & \\
\hline 5. Grade Point Average & 7.33 & .90 & & .11 & -.16 & .16 & .13 & & \\
\hline 6. Identification with Leader & 2.75 & 1.21 & .90 & $.46^{* *}$ & -.12 & -.11 & .04 & -.07 & \\
\hline 7. Leader Efficacy & 2.94 & 1.02 & .86 & $.41^{* *}$ & -.10 & $-.15^{*}$ & -.04 & -.08 & $.85^{*}$ \\
\hline
\end{tabular}

Note. ${ }^{a}$ scored -1 negative display, 1 positive display; ${ }^{\mathrm{b}}$ scored 0 females, 1 males; $\mathrm{n}=172 ;{ }^{*} \mathrm{p}<.05,{ }^{* *} \mathrm{p}<.01$.

We then conducted a series of ANOVA tests to verify our hypotheses. First, we tested the effect of emotion displays on the dependent variable 'perception of leader efficacy.' Results showed a significant difference between the groups $(\mathrm{F}=21.83 ; \mathrm{p}<0.001)$ (Table 3). Post-hoc tests (Tukey HSD) indicated that although the perceived efficacy of the authentic leader was higher when he displayed positive affect $(\bar{X}=3.37)$, the difference was not significant when compared to the control group $(\bar{X}=3.28)$, and therefore, results did not support hypothesis 1 . However, perceived efficacy in experimental group 2 (negative affective display) $(\bar{X}=2.37$ ) was significantly lower than the control group and experimental group 1, thus supporting hypothesis 2 .

Next, we tested the effect of authentic leader emotion displays on the dependent variable 'identification with the leader.' Results showed a significant difference between the groups ( $\mathrm{F}=$ 32.00; $\mathrm{p}<0,001$ ) (Table 3). Post-hoc tests indicated that although identification with the leader was higher when the authentic leader displayed positive affect $(\bar{X}=3.37)$, it was not significantly higher when compared to the control group $(\bar{X}=3.22)$. Therefore, hypothesis 3 was not supported. However, identification with the leader in the control group and experimental group 1 (positive affective display) were both significantly higher than in experimental group 2 (negative affective display) $(\overline{\mathrm{X}}=2.38)$, thus supporting hypothesis 4 . 
Table 3

ANOVA and post-hoc tests for attribution of leader efficacy and identification

\begin{tabular}{|c|c|c|c|c|c|c|}
\hline \multirow{8}{*}{ Leader Efficacy } & \multirow{2}{*}{\multicolumn{2}{|c|}{ Differences Between Groups }} & \multicolumn{2}{|c|}{ ANOVA } & \multicolumn{2}{|c|}{ Tukey HSD } \\
\hline & & & $\mathrm{F}$ & Sigma & Difference & Sigma \\
\hline & \multirow{2}{*}{ Control } & Positive & \multirow{6}{*}{21.83} & \multirow{6}{*}{0.000} & -.09 & .86 \\
\hline & & Negative & & & $.92^{*}$ & .00 \\
\hline & \multirow{2}{*}{ Positive } & Control & & & .09 & .86 \\
\hline & & Negative & & & $1.00^{*}$ & .00 \\
\hline & \multirow{2}{*}{ Negative } & Control & & & $-.92^{*}$ & .00 \\
\hline & & Positive & & & $-1.00^{*}$ & .00 \\
\hline \multirow{8}{*}{ Identification } & \multirow{2}{*}{\multicolumn{2}{|c|}{ Differences Between Groups }} & \multicolumn{2}{|c|}{ ANOVA } & \multicolumn{2}{|c|}{ Tukey HSD } \\
\hline & & & $\mathrm{F}$ & Sigma & Difference & Sigma \\
\hline & \multirow{2}{*}{ Control } & Positive & \multirow{6}{*}{32.00} & \multirow{6}{*}{0.000} & -.02 & .99 \\
\hline & & Negative & & & $1.31^{*}$ & .00 \\
\hline & \multirow{2}{*}{ Positive } & Control & & & .02 & .99 \\
\hline & & Negative & & & $1.33^{*}$ & .00 \\
\hline & \multirow{2}{*}{ Negative } & Control & & & $-1.31^{*}$ & .00 \\
\hline & & Positive & & & $-1.33^{*}$ & .00 \\
\hline
\end{tabular}

Note. Differences between means are significant at .05 level.

Figure 1 shows the means observed for the two variables, leader efficacy and identification with the leader, for the three groups. Negative affective displays significantly influenced follower assessments of effectiveness and identification with the authentic leader, leading to less favorable perceptions, while positive affective displays did not change such evaluations in comparison with the control group (neutral affect).

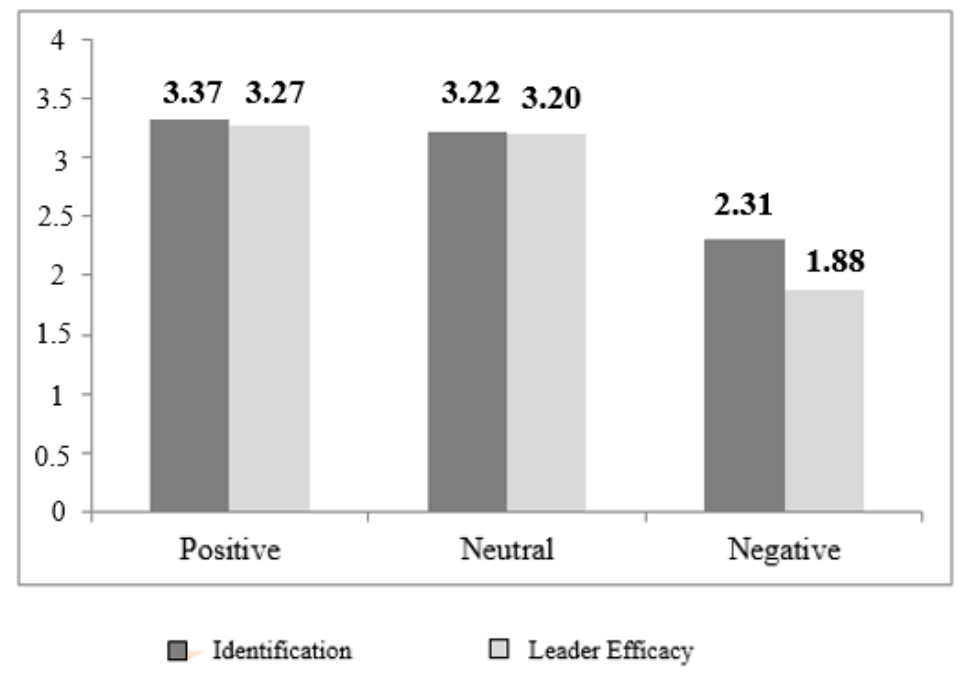

Figure 1. Means for identification and leader efficacy — study 1 
As a follow-up test, we analyzed if affective displays influenced participants' assessments of authentic leadership. Results from ANOVA showed similar results to those in the hypotheses tests. While there were significant differences between the groups $(F=20.95, p>.000)$, post-hoc tests (Tukey HSD) indicated that although scores for authentic leadership were higher when the leader displayed positive affect $(\bar{X}=3.57, \mathrm{SD}=0.55)$, the difference was not significant when compared to the control group $(\overline{\mathrm{X}}=3.43, \mathrm{SD}=0.61)$. Still, scores for authentic leadership were significantly lower in experimental group 2 (negative affective display) $(\overline{\mathrm{X}}=2.84, \mathrm{SD}=0.76$ ).

\section{Discussion}

Results from study 1 provide evidence that negative affective displays cast a shadow on evaluations of authentic leaders, negatively influencing followers' perception of leader efficacy and their identification with the leader. This indicates that when an authentic leader expresses negative affect, such as sadness, followers tend to appraise the leader as less effective and to identify less with this leader. These results are in line with those reported by Lewis (2000), McColl-Kennedy and Anderson (2002), and Gaddis, Connelly, and Mumford (2004) with respect to the substantial negative impact of negative displays on assessments of transformational leadership, which according to our results is a finding that can be extended to authentic leaders.

On the other hand, the results did not provide evidence that positive affective displays had a significant impact on followers' perception of leader efficacy and their identification with the leader when compared to positive affective displays and their lack thereof. These results for authentic leaders stand in contrast to what was observed in the study of transformational and charismatic leadership (Bono \& Ilies, 2006), and suggest that when leaders endorse attributes of authentic leadership, such as moral integrity and selflessness, positive affective displays do not notably alter follower attitudes about the leader when compared to a neutral display.

\section{EXPERIMENT - STUDY 2}

\section{Design}

We hired a professional actor who recorded videos playing the role of CEO for a fictitious company. In the videos, the CEO presents the company to new employees, endorsing inauthentic principles in his speech. The speech was developed based on items from the Authentic Leadership Questionnaire (ALQ - distributed by Mind Garden, Inc. -www.mindgarden.com, retrieved on February 11, 2015); however, we edited sentences to express values and ideas that oppose authentic leadership, i.e., inauthentic leader principles. The same text used in experiment 1 was adapted to form statements endorsing deception (lack of transparency), immoral behaviors such as cheating (lack of moral standards), callousness (lack of self-awareness), and arrogance (lack of balanced processing). The actor recorded four videos with the same content, while displaying positive emotions - experimental condition (1), passive negative emotions (sadness) experimental condition (2), active negative emotions (anger) - experimental condition (3), and a control video with the actor delivering the same speech with a neutral emotional tone.

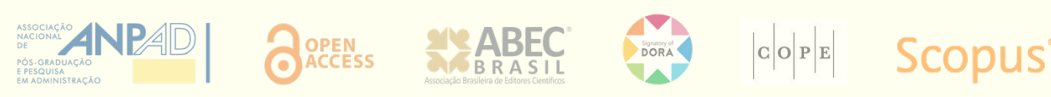




\section{Participants}

A sample comprised of 275 undergraduate majors from seven different colleges from a southeastern state, all enrolled in a joint distance program, participated in the study. One hundred and fifty-four participants were males (56\%), and 121 were females (44\%). The average age was 32 years $(\mathrm{SD}=9.5)$. Most participants were employed in full-time jobs, with an average length of work experience of 11 years. Participants were randomly assigned to participate in one of four groups. Each group watched a video corresponding to one of the three experimental conditions or the control group. The total number of participants per group was 68 in experimental condition 1 (positive emotion display), 73 in experimental condition 2 (active negative emotion display), 70 in experimental condition 3 (passive negative emotion display), and 64 in the control group.

\section{Table 4}

\section{Demographic and descriptive statistics by conditions - study 2}

\begin{tabular}{ccccc}
\hline Variables & Positive & Active Negative & Passive Negative & Control \\
\hline Gender & $41.1 \% \mathrm{~F} 58.9 \% \mathrm{M}$ & $41.4 \% \mathrm{~F} 58.6 \% \mathrm{M}$ & $39.7 \% \mathrm{~F} 60.3 \% \mathrm{M}$ & $53.1 \% \mathrm{~F} 46.9 \% \mathrm{M}$ \\
Age & $\bar{X}=33.7 \mathrm{SD}=10.7$ & $\bar{X}=32.0 \mathrm{SD}=9.0$ & $\bar{X}=33.2 \mathrm{SD}=9.2$ & $\bar{X}=32.5 \mathrm{SD}=8.6$ \\
Work Experience & $\bar{X}=12.5 \mathrm{SD}=10.8$ & $\bar{X}=11.5 \mathrm{SD}=9.1$ & $\bar{X}=11.3 \mathrm{SD}=8.9$ & $\bar{X}=10.2 \mathrm{SD}=7.6$ \\
Grade Point Average & $\bar{X}=6.9 \mathrm{SD}=1.3$ & $\bar{X}=6.5 \mathrm{SD}=1.8$ & $\bar{X}=6.7 \mathrm{SD}=1.6$ & $\bar{X}=6.6 \mathrm{SD}=1.5$ \\
Participants & 68 & 70 & 73 & 64 \\
\hline
\end{tabular}

\section{Procedure}

All students were enrolled in distance education courses jointly offered by a consortium of seven colleges at the State Center for Distance Learning. Data were collected using an electronic questionnaire developed with the Qualtrics tool (www.qualtrics.com, retrieved on February 7, 2015). Invitations to participate in the study were sent through email to all students active in the distance education platform. As for ethical aspects, the participants received a free and informed consent form stating the objective of the research, its context, the voluntary nature of their participation, guarantees regarding the anonymity and confidentiality of the information provided, the right to withdraw from the research at any time, as well as the necessary guidelines for the correct filling of the questionnaire. The invitation message contained a link leading to the survey, which initially directed participants to the informed consent. Then, participants watched one of the four videos, chosen at random by the Qualtrics software. After watching the video, participants filled in a questionnaire. 


\section{Measures}

'Affective states' - We applied the 15-item questionnaire developed by McNair et al. (1971) to assess the participants' judgment of the leader's emotional state. Some examples of items are:

"The leader is happy" and "The leader is despondent."

Participants evaluated the leader by scoring the items on a seven-point scale ranging from (1) totally incorrect to (7) totally correct. Cronbach's alpha of this study was .82 .

'Perception of leader efficacy' - We formulated three items to assess attributions about the leader's efficacy:

"This CEO is a good leader," "My productivity would increase with a leader like this," and "I think this leader would perform well in my area of work."

Participants ranked the leader's efficacy on a five-point Likert scale. Cronbach's alpha of this scale was .92.

'Identification with the leader' - We formulated three items to assess follower identification with the leader. These items were:

"This CEO fits my image of a leader," "I identify with this leader," and "I'd like to have this CEO as my formal leader."

Participants evaluated their degree of identification with the leader on a five-point Likert scale. Cronbach's alpha of this scale was .89 .

'Leader ethicality' - We used the Ethical Leadership Scale (ELS) developed by Brown, Trevino, and Harrison (2005). The instrument aims to evaluate ethical leadership as perceived by followers. It comprises ten items. Some examples are

"The leader ethically conducts his/her team" and "The leader sets an example of how to do things the right way regarding ethics."

Participants evaluated the leader by scoring the items on a seven-point Likert scale. The Cronbach's alpha of this scale is .85 .

'Demographic data' - We asked the participants to answer additional questions on gender, age, grade point average, whether they were working, and how many years of work experience they had. 


\section{Results}

Initially we verified the effect of the experimental manipulation of leader emotion display: positive, active negative, and passive negative. We evaluated differences between the groups for three independent subscales: (1) positive affect, (2) active negative affect (irritation/anger), and (3) passive negative affect (sadness/dismay). The first ANOVA, for the 'positive affect' subscale, showed that there were significant differences between the groups $(F=31.17, p<0.05)$. We performed a post-hoc test (Tukey HSD) to obtain multiple comparisons between the groups. In experimental group 1 (positive affect) participants' assessments of the inauthentic leader's affectivity were significantly higher $(\bar{X}=5.87$; $S D=0.95)$ than in the control group $(\bar{X}=5.27$; SD $=1.07)$, in experimental group 2 (active negative affect) $(\bar{X}=5.10 ; S D=0.97$ ), and in experimental group 3 (passive negative affect) $(\bar{X}=4.13 ; \mathrm{SD}=1.30)$.

The ANOVA for the 'active negative affect' subscale also showed that there were significant differences between the groups $(F=15.92, p<0.05)$. Post-hoc tests indicated that in experimental group 2 (active negative affect) participants' assessments of the inauthentic leader's affectivity were significantly higher $(\bar{X}=3.79$; SD $=1.38$ ) than in experimental group 3 (passive negative affect) $(\bar{X}=3.02 ; \mathrm{SD}=1.43)$, in the control group $(\bar{X}=2.61 ; \mathrm{SD}=1.33)$, and in experimental group 1 (positive affect) $(\bar{X}=2.20 ; \mathrm{SD}=1.48)$. We observed similar results in the ANOVA for the 'passive negative affect' subscale $(\mathrm{F}=21.98, \mathrm{p}<0.05)$. In experimental group 3 (passive negative affect) participants' assessments of the inauthentic leader's affectivity were significantly higher $(\bar{X}=3.37 ; S D=1.55)$ than in experimental group 2 (active negative affect) $(\bar{X}=2.23$; SD $=1.22)$, in the control group $(\bar{X}=2.17 ; \mathrm{SD}=1.17)$ and in experimental group 1 (positive affect) $(\bar{X}=1.74 ; S D=0.97)$. These results confirmed that the manipulation of emotion displays was successful for the three experimental conditions.

Table 5 displays the descriptive statistics, Pearson correlations, and Cronbach's alphas for the variables in the study. The dependent constructs 'leader efficacy,' 'identification with the leader,' and 'leader ethicality' had good internal consistency. As expected, there were no systematic differences between the experimental groups and the demographic variables and there were significant variations in the dependent variables between the conditions. Judgments about the leader were in general more stringent for older, more experienced individuals. 
Table 5

Descriptive statistics, Pearson correlations, and Cronbach's alphas

\begin{tabular}{|c|c|c|c|c|c|c|c|c|c|c|}
\hline Variables & AVG & SD & $\mathrm{Ca}$ & 1 & 2 & 3 & 4 & 5 & 6 & 7 \\
\hline 1. Condition ${ }^{a}$ & - & - & & & & & & & & \\
\hline 2. Gender $^{b}$ & - & - & & .03 & & & & & & \\
\hline 3. Age & 32.88 & 9.38 & & .05 & $-.20^{* *}$ & & & & & \\
\hline 4. Experience & 11.41 & 9.17 & & .02 & $-.27^{* *}$ & $.85^{* *}$ & & & & \\
\hline 5. Grade Point Average & 7.25 & 5.53 & & -.02 & -.06 & .03 & .02 & & & \\
\hline 6. Leader Efficacy & 2.45 & 1.28 & .89 & $.21^{* *}$ & .07 & $-.13^{*}$ & $-.15^{*}$ & -.09 & & \\
\hline 7. Identification with Leader & 2.35 & 1.29 & .92 & $.21^{* *}$ & .09 & $-.12^{*}$ & $-.13^{*}$ & -.09 & $.92^{* *}$ & \\
\hline 8. Leader Ethicality & 3.20 & 1.74 & .85 & $.15^{*}$ & .11 & $-.21^{* *}$ & $-.21^{* *}$ & -.06 & $.76^{* *}$ & $.77^{* *}$ \\
\hline
\end{tabular}

Note. A scored -1 negative active display, 1 positive display; $b$ scored 0 females, 1 males; $n=275 ;{ }^{*} p<.05,{ }^{* *} p<.01$.

We then conducted a series of ANOVA tests to verify our hypotheses. We tested the effect of emotion displays on the dependent variable 'leader efficacy.' The ANOVA results showed a significant difference between the groups $(F=5.73, p<0.05)$ (Table 6). Comparisons of the means using the Tukey HSD test indicated that assessments of leaders' efficacy for experimental group 1 (positive display) were significantly higher $(\bar{X}=2.80 ; \mathrm{SD}=1.38$ ), followed by experimental group 3 (passive negative) $(\overline{\mathrm{X}}=2.26 ; \mathrm{SD}=1.33)$, and by experimental group 2 (active negative) $(\overline{\mathrm{X}}=2.11$; $\mathrm{SD}=0.99)$ (Figure 5). All differences between the groups were significant, except between the two negative conditions (experimental groups 2 and 3). The results supported hypotheses 5a and 5b.

Then we tested the effect of emotion displays on the dependent variable 'identification with the leader.' The ANOVA results showed a significant difference between the groups in their identification with the inauthentic leader $(F=5.78, p<0.05)$. Comparisons of the means using the Tukey HSD test indicated that participants' identification with the inauthentic leader was significantly higher for experimental group 1 (positive affect) $(\bar{X}=2.17 ; \mathrm{SD}=1.35$ ), followed by experimental group 3 (passive negative) $(\bar{X}=2.13$; SD $=1.33$ ), and experimental group 2 (active negative) $(\bar{X}=2.05 ; \mathrm{SD}=1.04)$. All differences between the groups were significant, except between the two negative conditions (experimental groups 2 and 3). The results supported hypotheses $6 \mathrm{a}$ and $6 \mathrm{~b}$. 
Table 6

ANOVA and post hoc for attribution of leader efficacy, identification, and ethical judgment

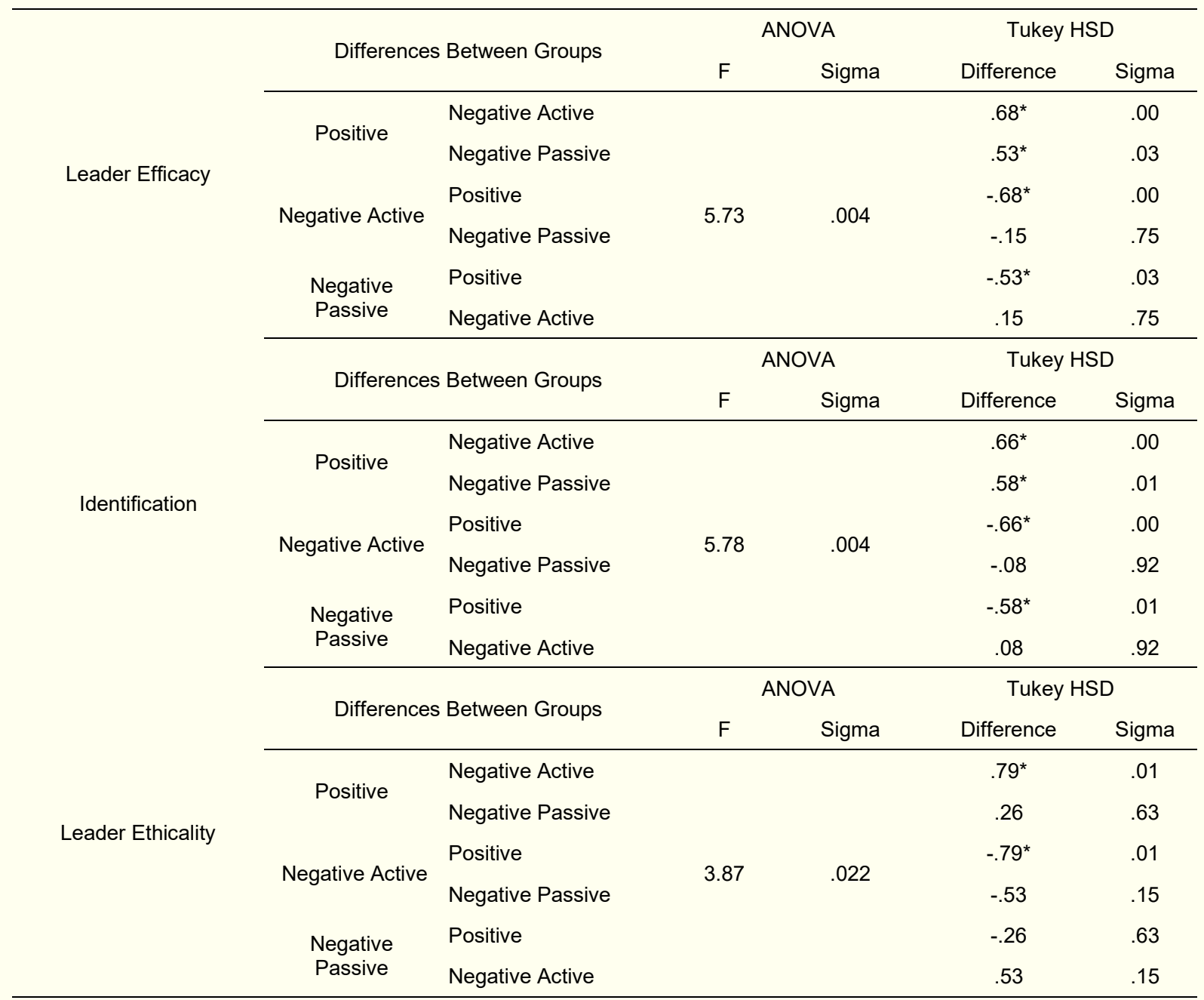

Note. Differences between means are significant for .05 level.

Finally, we tested the effect of inauthentic leader emotion displays on the dependent variable 'leader ethicality.' The ANOVA results showed a significant difference between the groups $(\mathrm{F}=3.87, \mathrm{p}<0.05)$. Comparisons of the means using the Tukey HSD test indicated that participants' judgments regarding the ethicality of the inauthentic leader was higher for experimental group 1 (positive emotion) $(\overline{\mathrm{X}}=3.53$; $\mathrm{SD}=1.88)$, followed by experimental group 3 (passive negative) $(\overline{\mathrm{X}}=3.27 ; \mathrm{SD}=1.78)$ and by experimental group 2 (active negative) $(\overline{\mathrm{X}}=2.74$; $\mathrm{SD}=1.49$ ). The results indicated a significant difference between group 1 (positive affect) and group 2 (active negative), supporting H7a. However, as shown in Table 6, the mean difference between experimental group 1 (positive affect) and experimental group 3 (passive negative) was not significant. Therefore, hypothesis $7 \mathrm{~b}$ was not supported. 
As can be seen in Figure 2, the judgments about the ethical behavior of the inauthentic leader who displayed passive negative emotions were considerably higher than those of the leader who displayed aggressive negative emotions $(\bar{X}=3.27$ and $\bar{X}=2.74$, respectively), a difference that was larger than the difference regarding perception of efficacy $(\bar{X}=2.26$ and $\bar{X}=2.11$, respectively) and personal identification $(\bar{X}=2.213$ and $\bar{X}=2.05$, respectively) for these same two groups. Therefore, we performed an additional test to compare the means in the judgment of ethical behaviors between these two conditions. The results of the ANOVA showed a marginally significant p-value $(F=3.73$ and sigma $=0.05)$, suggesting that there is a considerable difference in the judgments about the ethical conduct of the inauthentic leader who displayed passive negative emotions and the one who displayed active negative emotions, with more stringent judgments regarding the ethical behavior of the latter. This result confirms $\mathrm{H} 8$.

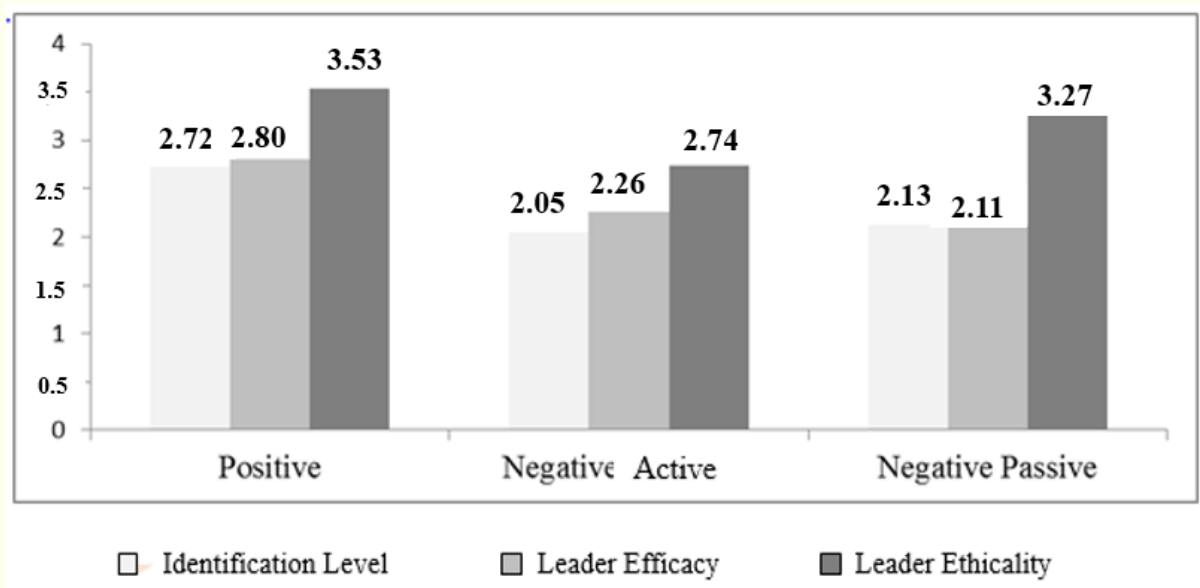

Figure 2. Means for identification, leader efficacy, and leader ethicality - study 2

\section{Discussion}

Study 2 showed that the inauthentic leader who displayed positive emotions was appraised more highly for effectiveness and inspired greater identification compared to the leaders who presented negative affect. However, there were no differences in attitudes of followers when leaders display passive versus active negative emotions. On the other hand, the expression of positive emotions led to more favorable opinions about the leader's ethicality when compared to all conditions. Besides, when the inauthentic leader displayed active negative emotions he was considered less ethical than when he displayed passive negative emotions.

The finding that positive emotions favor the judgments about inauthentic leaders is in line with previous studies concerning leaders in general (Bono \& Ilies, 2006; Johnson, 2008; Joseph et al., 2015; Lewis, 2000; Sadri et al., 2011; Visser, Van Knippenberg, Van Kleef, \& Wisse, 2013). The expression of aggressive negative emotions triggered more severe judgments about the ethicality of the inauthentic leader (Madera \& Smith, 2009), particularly compared with inauthentic leaders who displayed positive and passive negative emotions, regardless of the inauthentic content of their communications. Therefore, the display of positive emotions functioned as a

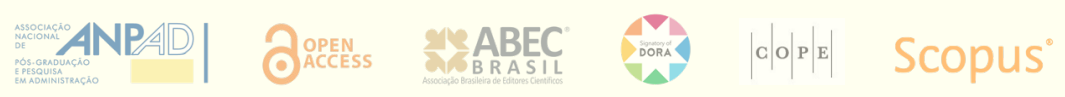


filter, attenuating judgments about the ethicality of an openly immoral leader, while the display of negative active emotion led to more stringent judgments about the same leader.

\section{CONCLUSION AND FINAL CONSIDERATIONS}

Emotions have a profound effect on interpersonal relationships and can help leaders drive results and overall performance in the workplace. Nevertheless, they can also play a role in impression management and intentional manipulation of others in the quest for personal aggrandizement. Therefore, our central objective was to test the interplay between principled leadership and affective displays. In this study, we focused on positive displays (happiness/enthusiasm), passive negative ones (sadness/dismay), and active negative ones (irritation/anger), and how such displays affected followers' perceptions of leader efficacy, their identification with the leader and their judgments about the leader's ethicality. We conducted two experimental studies in the context of distant leadership, centering on the precepts of the authentic leadership framework.

The theory of authentic leadership has proposed the importance of emotions for leadership (Avolio et al., 2017; Michie \& Gooty, 2005). Some authors also believe that the theory pays more heed to emotional and affective elements than to cognitive ones when compared to previous leadership approaches (Lord \& Brown, 2004). However, in analyzing the emotional expressions of a leader, we observed that positive affective displays did not influence evaluations about the authentic leader when compared to a neutral emotional tone (control group). On the other hand, negative affective displays led to a harsher judgment in the appraisals of an authentic leader. In other words, when the leader's discourse emphasized values and practices associated with authentic principles, displays of positive emotions did not influence followers' judgments about the leader, but displays of negative emotions functioned as a lens that tainted the leader's image, leading to less favorable assessments, despite the moral principles and values openly advocated by the leader.

In contrast, displays of positive affect favored followers' assessment of an inauthentic leader. When the inauthentic leader displayed positive emotions, it elicited better appraisals regarding his effectiveness and stimulated closer identification when compared to displays of negative emotions and in contrast to a neutral emotional tone (control group). This result suggests that even leaders that endorse openly inauthentic principles in discourse will be viewed more favorably when they convey positive emotions in non-verbal communication. Positive emotion displays even influenced followers' judgments about the morality of an inauthentic leader, particularly when compared with displays of active negative emotions, a condition that led to more severe judgments about the leader's ethicality.

Since the same actor in the same scenario delivered similar speeches in content and length across the two studies (except for the parts when he endorses principled and unprincipled conduct), it is worth observing that effectiveness and identification with the leader were higher for an unprincipled leader displaying positive affect than for a principled leader displaying passive negative affect. These results are particularly striking and should prompt deeper reflection about daily

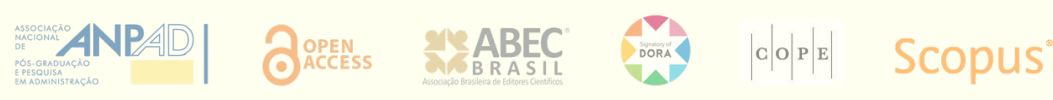


interpersonal exchanges in both politics and business, since they show that inauthentic leaders with a positive outlook, be it through the process of cognitive processing or emotional contagion, will be judged less harshly by followers even when they openly endorse behaviors that are morally questionable.

In addition, the inauthentic leader that expressed passive negative emotions was on average appraised just as negatively as the counterpart active negative leader, but judgments about the former leader's ethical conduct were less severe. We speculate that a sad and dismayed inauthentic leader can be perceived as a victim, triggering feelings of pity in followers, or be perceived as unthreatening, minimizing the impact of toxic effects. In contrast, aggressive negative emotion display in an inauthentic leader elicited more harsh judgments. Thus, it appears that active negative displays sharpen the perception of toxicity, more clearly highlighting inauthentic leadership.

This study contributes to the literature in several ways. First, by investigating authentic leadership using experimental designs, which allows us to establish causality and enhances the internal validity of our study. In addition, it does so while exploring a key element in social interaction and leadership process: the emotion displays of leaders. While studies on the interplay between principled leadership and emotion displays are scarce, to the best of our knowledge, no previous research has investigated such issues in regard to authentic leadership. Also, it adds knowledge regarding how unprincipled leaders influence followers, bringing attention to the role of their emotion displays on followers' assessments of their effectiveness and ethicality. Our study also offers an original and conceptually sound definition of inauthentic leadership, although preliminary, which can bring momentum to studies about toxic leadership, as it highlights behavioral aspects relevant to social influence.

Since we investigated perceptions about leaders applying an experimental design, our findings reinforce the causal relationship between emotional displays and follower judgments about principled and unprincipled leaders. We also observed that judgments about a leader tended to be more stringent among older, more experienced participants. This reinforces the importance of randomized designs, such as the ones applied in our studies, in future experimental research, as well as the need to control of such factors in surveys that investigate leadership perceptions in student samples.

Nevertheless, while laboratory experimental designs assure stronger internal validity, some external validity is compromised, which is a limitation of this study. In addition, observations about the leader in both studies were restricted to one single event in the context of distant leadership. Therefore, the conclusions and its extension to closer and long-lasting interpersonal exchanges between (in)authentic leaders and their followers cannot be made. Future experimental studies can further address the role of leader emotion displays and authentic leadership by applying designs where leader and followers engage in substantive, extended interactions. Studies can also take advantage of event-level methodological approaches to analyze leaders' affective displays and internal follower processes in dynamic exchanges.

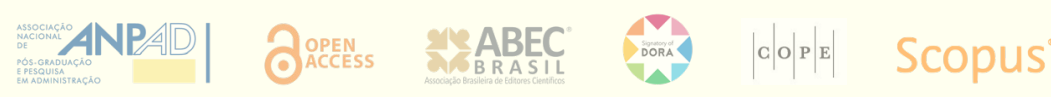


In addition, since participants in our study are all undergraduate senior students, we cannot extend our findings to a larger, more diverse population. For future studies, we suggest that the interplay between affective displays and principled leadership could be analyzed with diverse samples. Future research can also extend knowledge by investigating the effects of positive and negative feelings of followers, and their influences on preference for and assessments about authentic and inauthentic leaders. Studies should also explore a broader array of leader affective expressions, including moral and empathetic emotions.

\section{Funding}

Flavia Cavazotte gratefully acknowledges the support received from the Brazilian National Council for Scientific and Technological Development (CNPq) - Research Grant 307186/20180 (Productivity in Research).

\section{REFERENCES}

Antonakis, J., \& Atwater, L. (2002). Leader distance: A review and a proposed theory. The Leadership Quarterly, 13(6), 673-704. https://doi.org/10.1016/S1048-9843(02)00155-8

Avolio, B. J., \& Gardner, W. L. (2005). Authentic leadership development: Getting to the root of positive forms of leadership. The Leadership Quarterly, 16(3), 315-338. https://doi.org/10.1016/j.leaqua.2005.03.001

Avolio, B. J., Gardner, W. L., Walumbwa, F. O., Luthans, F., \& May, D. R. (2004). Unlocking the mask: A look at the process by which authentic leaders impact follower attitudes and behaviors. The Leadership Quarterly, 15(6), 801-823. https://doi.org/10.1016/i.leaqua.2004.09.003

Avolio, B. J., Wernsing, T., \& Gardner, W. L. (2017). Revisiting the development and validation of the authentic leadership questionnaire: Analytical clarifications. Journal of Management, 44(2), 399-411. https://doi.org/10.1177/0149206317739960

Barsade, S. (2002). The ripple effect: Emotional contagion and its influence on group behavior. Administrative Science Quarterly, 47(4), 644-675. https://doi.org/10.2307/3094912

Bass, B. M., \& Steidlmeier, P. (1999). Ethics, character, and authentic transformational leadership behavior. The Leadership Quarterly, 10(2), 181-217. https://doi.org/10.1016/S1048-9843(99)00016-8

Bass, B. M. (1999). Two decades of research and development in transformational leadership. European Journal of Work and Organizational Psychology, 8, 9-32. https://doi.org/10.1080/135943299398410

Bono, J. E., \& Ilies, R. (2006). Charisma, positive emotions and mood contagion. The Leadership Quarterly, 17(4), 317-334. https://doi.org/10.1016/j.leaqua.2006.04.008

Bradfield, M., \& Aquino, K. (1999). The effects of blame attributions and offender likableness on forgiveness and revenge in the workplace. Journal of Management, 25(5), 607-631. https://doi.org/10.1177/014920639902500501

Brief, A. P., \& Weiss, H. M. (2002). Organizational behavior: Affect in the workplace. Annual Review of Psychology, 53(1), 279-307. https://doi.org/10.1146/annurev.psych.53.100901.135156

Brown, M., Trevino, L., \& Harrison, D. (2005). Ethical leadership: A social learning perspective for construct development and testing. Organizational Behavior and Human Decision Processes, 97(2), 117-134. https://doi.org/10.1016/j.obhdp.2005.03.002

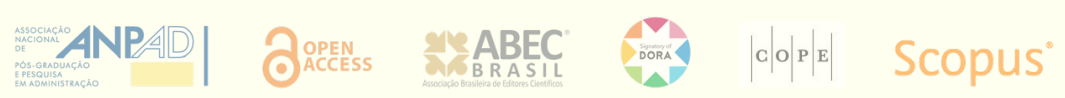


Burns J. M. (1978). Leadership. New York: Harper \& Row.

Chi, N. W., Chung, Y. Y., \& Tsai, W. C. (2011). How do happy leaders enhance team success? The mediating roles of transformational leadership, group affective tone, and team processes 1. Journal of Applied Social Psychology, 41(6), 1421-1454. https://doi.org/10.1111/j.1559-1816.2011.00767.x

Conger, J. A. (1990). The dark side of leadership. Organizational dynamics, 19(2), 44-55. https://doi.org/10.1016/0090-2616(90)90070-6

Damen, F., Van Knippenberg, D., \& Van Knippenberg, B. (2008). Leader affective displays and attributions of charisma: The role of arousal. Journal of Applied Social Psychology, 38(10), 2594-2614. https://doi.org/10.1111/j.1559-1816.2008.00405.x

Dasborough, M. T., \& Ashkanasy, N. M. (2005). Follower emotional reactions to authentic and inauthentic leadership influence. In Authentic leadership theory and practice: Origins, effects and development (pp. 281-300). Oxford (UK): Elsevier.

Den Hartog, D. N., \& Belschak, F. D. (2012). Work engagement and Machiavellianism in the ethical leadership process. Journal of Business Ethics, 107(1), 35-47. https://doi.org/10.1007/s10551-012-1296-4

Deluga, J. (2001). American presidential Machiavellianism implications for charismatic leadership and rated performance. The Leadership Quarterly, 12(3), 339-363. https://doi.org/10.1016/S1048-9843(01)00082-0

Dinh, J. E., Lord, R. G., Gardner, W. L., Meuser, J. D., Liden, R. C., \& Hu, J. (2014). Leadership theory and research in the new millennium: Current theoretical trends and changing perspectives. The Leadership Quarterly, $25(1), 36$ 62. https://doi.org/10.1016/j.leaqua.2013.11.005

Erez, A., Misangyi, V. F., Johnson, D. E., LePine, M. A., \& Halverson, K. C. (2008). Stirring the hearts of followers: charismatic leadership as the transferal of affect. Journal of Applied Psychology, 93(3), 602. https://doi.org/10.1037/0021-9010.93.3.602

Fehr, R., Yam, K., \& Dang C. (2015) Moralized leadership: The construction and consequences of ethical leader perceptions. Academy of Management Review, 40(2), 182-209. https://doi.org/10.5465/amr.2013.0358

Gaddis, B., Connelly, S., \& Mumford, M. D. (2004). Failure feedback as an affective event: Influences of leader affect on subordinate attitudes and performance. The Leadership Quarterly, 15(5), 663-686. https://doi.org/10.1016/j.leaqua.2004.05.011

Gardner, J. W. (1990) On Leadership. New York: Free Press.

Gardner, W. L., \& Avolio, B. J. (1998). The charismatic relationship: A dramaturgical perspective. Academy of management review, 23(1), 32-58. https://doi.org/10.5465/amr.1998.192958

Gardner, W. L., Avolio, B. J., Luthans, F., May, D. R., \& Walumbwa, F. O. (2005). "Can you see the real me?" A self-based model of authentic leader and follower development. The Leadership Quarterly, 16(3), 343-372. https://doi.org/10.1016/j.leaqua.2005.03.003

Gardner, W. L., Cogliser, C. C., Davis, K. M., \& Dickens, M. P. (2011). Authentic leadership: A review of the literature and research agenda. The Leadership Quarterly, 22(6), 1120-1145. https://doi.org/10.1016/j.leaqua.2011.09.007

George, J. M. (1996). Group affective tone. In M. West (Ed.), Handbook of work group psychology (pp. 77-93). Sussex, England: Wiley.

George, W. (2003). Authentic leadership: Rediscovering the secrets to creating lasting value. San Francisco: Jossey-Bass.

Gooty, J., Connelly, S., Griffith, J., \& Gupta, A. (2010). Leadership, affect and emotions: A state of the science review. The Leadership Quarterly, 21(6), 979-1004. https://doi.org/10.1016/j.leaqua.2010.10.005

Grossman, R. J. (2000). Emotions at work. Health Forum Journal, 43(5), 18-22.

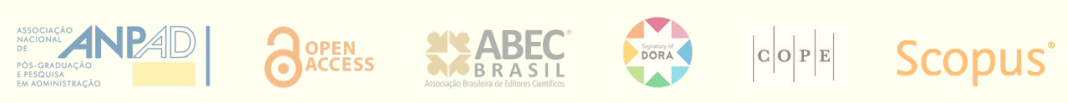


Haidt, J. (2003). The moral emotions. In R. J. Davidson, K. R. Scherer, \& H. H. Goldsmith (Eds.). Handbook of Affective Science (pp. 852-870). Oxford, UK: Oxford University Press.

Harvey, P., Harris, K. J., Gillis, W. E., \& Martinko, M. J. (2014). Abusive supervision and the entitled employee. The Leadership Quarterly, 25(2), 204-217. https://doi.org/10.1016/j.leaqua.2013.08.001

Hatfield, E., Cacioppo, J., \& Rapson, R. (1992). Primitive emotional contagion. In: M. S. Clark (Ed.), Review of Personality and Social Psychology (pp. 151-177). Newbury Park, CA: Sage.

Henderson, J. E., \& Hoy, W. K. (1983). Leader authenticity: The development and test of an operational measure. Educational and Psychological Research, 3(2), 63-75. Retrieved from https://www.researchgate.net/publication/232547195_Leader_authenticity_The_development_and_test_of_a n_operational_measure

Ilies, R., Fulmer, I. S., Spitzmuller, M., \& Johnson, M. D. (2009). Personality and citizenship behavior: The mediating role of job satisfaction. Journal of Applied Psychology, 94(4), 945-59. https://doi.org/10.1037/a0013329

Johnson, S. K. (2008). Second that emotion: Effects of emotional contagion and affect at work on leader and follower outcomes. The Leadership Quarterly, 19(1), 1-19. https://doi.org/10.1016/j.leaqua.2007.12.001

Johnson, S. K. (2009). Do you feel what I feel? Mood contagion and leadership outcomes. The Leadership Quarterly, 20(5), 814-827. https://doi.org/10.1016/j.leaqua.2009.06.012.

Joseph, D. L., Dhanani, L. Y., Shen, W., Mchugh, B. C., \& Mccord, M. A. (2015). Is a happy leader a good leader? A meta-analytic investigation of leader trait affect and leadership. The Leadership Quarterly, 26(4), 557-576. https://doi.org/10.1016/j.leaqua.2015.04.001

Kant, L., Skogstad, A., Torsheim, T., \& Einarsen, S. (2013). Beware the angry leader: Trait anger and trait anxiety as predictors of Petty Tyranny. The Leadership Quarterly, 24(1), 106-124. https://doi.org/10.1016/j.leaqua.2012.08.005

Kirkpatrick S. A., \& Locke E. A. (1991). Leadership: do traits matter? Academy of Management Executive, 5(2), 48-60. https://doi.org/10.5465/ame.1991.4274679

Koning, F., \& Kleef, G. V. (2015). How leader's emotional displays shape follower's organizational citizenship behavior. The Leadership Quarterly, 26(4), 489-501. https://doi.org/10.1016/j.leaqua.2015.03.001

Kunst, J. R., Dovidio, J. F. \& Thomsen, L. (2019). Fusion with political leaders predicts willingness to persecute immigrants and political opponents. Nature Human Behavior, 3,1180-1189. https://doi.org/10.1038/s41562-019-0708-1

Ladkin, D., \& Taylor, S. S. (2010). Enacting the 'true self' Towards a theory of embodied authentic leadership. The Leadership Quarterly, 21(1), 64-74. https://doi.org/10.1016/j.leaqua.2009.10.005

Lewis, K. M. (2000). When leaders display emotion: How followers respond to negative emotional expression of male and female leaders. Journal of Organizational Behavior, 21(2), 221-234. https://doi.org/10.1002/(SICI)10991379(200003)21:2<221::AID-JOB36>3.0.CO;2-0

Lord, R. G., \& Brown, D. J. (2004). Leadership processes and follower identity. Mahwah, NJ: Lawrence Erlbaum Associates.

Luthans, F., \& Avolio, B. J. (2003). Authentic leadership development. In K. S. Cameron, J. E. Dutton, \& R. E. Quinn (Eds.), Positive organizational scholarship. San Francisco: Berrett-Koehler.

Madera, J., \& Smith, D. B. (2009). The effects of leader negative emotions on evaluations of leadership in a crisis situation: the role of anger and sadness. The Leadership Quarterly, 20(2), 103-114. https://doi.org/10.1016/j.leaqua.2009.01.007

Matthiesen, S. B., \& Einarsen, S. (2007). Perpetrators and targets of bullying at work: Role stress and individual differences. Violence and Victims, 22(6), 735-753. http://doi.org/10.1891/088667007782793174

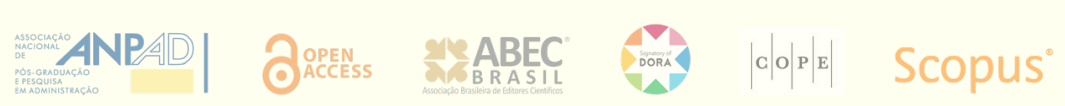


May, D. R., Chan, A. Y., Hodges, T. D., \& Avolio, B. J. (2003). Developing the moral component of authentic leadership. Organizational dynamics, 32(3), 247-260. https://doi.org/10.1016/S0090-2616(03)00032-9

Mccoll-Kennedy, J., \& Anderson, R. (2002). Impact of leadership style and emotions on subordinate performance. The Leadership Quarterly, 13(5), 545-559. https://doi.org/10.1016/S1048-9843(02)00143-1.

McNair, D. M., Lorr, M., \& Droppelman, L. F. (1971). Manual for the profile of mood states. San Diego, CA: Educational and Industrial Testing Service.

Michie, S., \& Gooty, J. (2005). Values, emotions, and authenticity: Will the real leader please stand up? The Leadership Quarterly, 16(3), 441-457. https://doi.org/10.1016/j.leaqua.2005.03.006

Montepare, J. M., \& Dobish, H. (2003). The contribution of emotion perceptions and their overgeneralizations to trait impressions. Journal of Nonverbal Behavior, 27(4), 237-254. https://doi.org/10.1023/A:1027332800296

Naseer, S., Raja, U., Syed, F., Donia, M. B. L., \& Darr, W. (2016). Perils of being close to a bad leader in a bad environment: Exploring the combined effects of despotic leadership, leader member exchange, and perceived organizational politics and behaviors. The Leadership Quarterly, 27(1), 14-33. https://doi.org/10.1016/j.leaqua.2015.09.005.

Neider, L., Schriesheim, C. (2011). The authentic leadership inventory: Development and empirical tests. The Leadership Quarterly, 22(6), 1146-1164. https://doi.org/10.1016/j.leaqua.2011.09.008

Neves, P. (2012). Organizational cynicism: Spillover effects on supervisor-subordinate relationships and performance. The Leadership Quarterly, 23(5), 965-976. https://doi.org/10.1016/j.leaqua.2012.06.006

Newcombe, M. J., \& Ashkanasy, N. M. (2002). The role of affect and effective congruence in perceptions of leaders: An experimental Study. The Leadership Quarterly, 13(5), 601-614. https://doi.org/10.1016/S1048-9843(02)00146-7.

Olivola, C. Y., Eubanks, D. L., \& Lovelace, J. B. (2014). The many (distinctive) faces of leadership: Inferring leadership domain from facial appearance. The Leadership Quarterly, 25(5), 817-834. https://doi.org/10.1016/j.leaqua.2014.06.002.

O’Reilly III, C. A., Doerr, B., Caldwell, D. F., \& Chatman, J. A. (2014). Narcissistic CEOs and executive compensation. The Leadership Quarterly, 25(2), 218-231. https://doi.org/10.1016/j.leaqua.2013.08.002.

Peus, C., Wesche, J. S., Streicher, B., Braun, S., \& Frey, D. (2012). Authentic leadership: An empirical test of its antecedents, consequences, and mediating mechanisms. Journal of Business Ethics, 107(3), 331-348. https://doi.org/10.1007/s10551-011-1042-3

Rajah, R., Song, Z., \& Arvey, R. D. (2011). Emotionality and leadership: Taking stock of the past decade of research. The Leadership Quarterly, 22(6), 1107-1119. https://doi.org/10.1016/j.leaqua.2011.09.006

Rubin, R. S., Dierdorff, E. C., Bommer, W. H., \& Baldwin, T. T. (2009). Do leaders reap what they sow? Leader and employee outcomes of leader organizational cynicism about change. The Leadership Quarterly, 20(5), 680-688. https://doi.org/10.1016/j.leaqua.2009.06.002

Sadri, G., Weber, T. J., \& Gentry, W. A. (2011). Empathic emotion and leadership performance: An empirical analysis across 38 countries. The Leadership Quarterly, 22(5), 818-830. https://doi.org/10.1016/j.leaqua.2011.07.005

Schyns, B., \& Schilling, J. (2013). How bad are the effects of bad leaders? A meta-analysis of destructive leadership and its outcomes. The Leadership Quarterly, 24(1), 138-158. https://doi.org/10.1016/j.leaqua.2012.09.001.

Seeman, M. (1966). Status and identity: The problem of inauthenticity. The Pacific Sociological Review, 9(2), 67-73 https://doi.org/10.2307/1388239

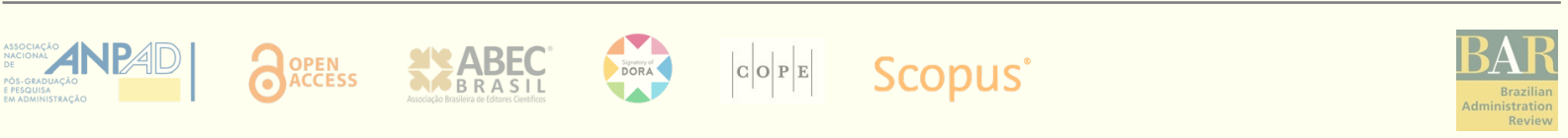


Spitzmuller, M., \& Ilies, R. (2010). Do they [all] see my true self? Leader's relational authenticity and followers' assessments of transformational leadership. European Journal of Work and Organizational Psychology, 19, 304-332. https://doi.org/10.1080/13594320902754040

Sutton, R. I., \& Rafaeli, A. (2017). Untangling the relationship between displayed emotions and organizational sales: The case of convenience stores. Academy of Management Journal, 31(3), 461-487. https://doi.org/10.5465/256456

Sy, T., Côté, S., \& Saavedra, R. (2005). The contagious leader: Impact of the leader's mood on the mood of group members, group affective tone, and group process. Journal of Applied Psychology, 90(2), 295-305. https://doi.org/10.1037/0021-9010.90.2.295

Tiedens, L. Z., \& Linton, S. (2001). Judgment under emotional uncertainty: The effects of specific emotions and their associated certainty appraisals on information processing. J Pers Soc Psychol, 81(6), 973-88. https://doi.org/10.1037//0022-3514.81.6.973

Trichas, S., \& Schyns, B. (2012). The face of leadership: Perceiving leaders from facial expression. The Leadership Quarterly, 23(3), 545-566. https://doi.org/10.1016/j.leaqua.2011.12.007

Van Knippenberg, D., \& Van Kleef, G. A. (2017). Leadership and affect: Moving the hearts and minds of followers. The Academy of Management Annals, 10(1), 799-840. https://doi.org/10.5465/19416520.2016.1160515

Van Kleef, G. A. (2009). How emotions regulate social life: The emotions as social information (EASI) model. Current directions in psychological science, 18(3), 184-188. https://doi.org/10.1111/j.1467-8721.2009.01633.x

Visser, V. A., Van Knippenberg, D. V., Van Kleef, G. V., \& Wisse, B. (2013). How leader displays of happiness and sadness influence follower performance: Emotional contagion and creative versus analytical performance. The Leadership Quarterly, 24(1), 172-188. https://doi.org/10.1016/j.leaqua.2012.09.003

Walumbwa, F. O., Avolio, B. J., Gardner, W. L., Wernsing, T. S., \& Peterson, S. J. (2008). Authentic leadership: Development and validation of a theory-based measure. Journal of Management, 34(1), 89-126. https://doi.org/10.1177/0149206307308913.

Wang, H., Sui, Y., Luthans, F., Wang, D., Wu, Y. (2014) Impact of authentic leadership on performance: Role of followers' positive psychological capital and relational processes. Journal of Organizational Behavior, 35(1), 5-21. https://doi.org/10.1002/job.1850

Watson, D., \& Clark, L. A. (1997). Measurement and mismeasurement of mood: Recurrent and emergent issues. Journal of Personality Assessment, 68, 267-296. https://doi.org/10.1207/s15327752jpa6802_4

Weiss, H. M., \& Cropanzano, R. (1996). Affective events theory: a theoretical discussion of the structure, causes and consequences of affective experiences at work. In, R. I. Sutton, \& B. M. Staw (Eds.), Research in organizational behavior (Vol. 18, pp. 1-74). Greenwich, CT: JAI Press.

Xu, A. J., Loi, R., \& Lam, L. W. (2015). The bad boss takes it all: How abusive supervision and leader-member exchange interact to influence employee silence. The Leadership Quarterly, 26(5), 763-774. https://doi.org/10.1016/j.leaqua.2015.03.002

\section{Authors' contributions}

$1^{\text {st }}$ author: conceptualization (equal), formal analysis (equal), funding acquisition (equal), methodology (equal), supervision (equal), writing-original draft (equal).

$2^{\text {nd }}$ author: conceptualization (equal), data curation (equal), methodology (equal), project administration (equal), resources (equal), visualization (equal), writing-original draft (equal).

$3^{\text {rd }}$ author: conceptualization (equal), data curation (equal), methodology (equal), project administration (equal), resources (equal), visualization (equal), writing-original draft (equal).

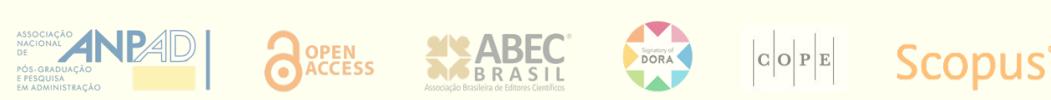




\section{Authors}

\section{Flávia Cavazotte}

Pontifícia Universidade Católica do Rio de Janeiro, IAG - Escola de Negócios

R. Marquês de São Vicente, no. 225, Gávea, 22541-041, Rio de Janeiro, RJ, Brazil

flavia.cavazotte@iag.puc-rio.br

(iD) https://orcid.org/0000-0002-5450-3573

\section{Daniel Martins Abelha*}

Pontifícia Universidade Católica do Rio de Janeiro, IAG - Escola de Negócios

R. Marquês de São Vicente, no. 225, Gávea, 22541-041, Rio de Janeiro, RJ, Brazil abelhadaniel@gmail.com, abelhadaniel@usp.br

(iD) https://orcid.org/0000-0002-8591-2257

\section{Lucas Martins Turano}

Pontifícia Universidade Católica do Rio de Janeiro, IAG - Escola de Negócios R. Marquês de São Vicente, no. 225, Gávea, 22541-041, Rio de Janeiro, RJ, Brazil lucas.turano2@gmail.com

(iD) https://orcid.org/0000-0002-8709-3910

* Corresponding author

Peer review is responsible for acknowledging an article's potential contribution to the frontiers of scholarly knowledge on business or public administration. The authors are the ultimate responsible for the consistency of the theoretical references, the accurate report of empirical data, the personal perspectives, and the use of copyrighted material.

This content was evaluated using the double-blind peer review process. The disclosure of the reviewers' information on the first page is made only after concluding the evaluation process, and with the voluntary consent of the respective reviewers. 